\title{
Testing Tephrosia Vogelii for Resistance to Foliar Blight in Puerto Rico
}

\author{
E. G. Ruppel, D. K. Barnes, R. H. Freyre, and Alma Santiago ${ }^{1}$
}

\section{INTRODUCTION}

Tephrosia vogelii Hook $\mathrm{f}$. is a tropical legume that has shown potential as a commercial source of the natural insecticide rotenone (2) ${ }^{2}$. A program to increase the concentration of rotenone in the leaves of $T$. vogelii was initiated at the Federal Experiment Station, Mayagüez, P.R., in 1957. Since the advent of this program, damping-off and foliar-blight diseases frequently have been encountered. Pellicularia filamentosa (Pat.) Rogers (= Thanatephorus cucumeris (Frank) Donk, Rhizoctonia solani Kuhn) (6) and Macrophomina phaseoli (Maubl.) Ashby (=Rhizoctonia bataticola (Taub.) Butl.) (4) are reported as the primary incitants of foliar blight. The former fungus also is reported to incite damping-off of young seedlings (3).

In 1963 certain breeding lines of $T$. vogelii in a nursery at Mayagüez, P.R., appeared to be less affected with foliar blight than other adjacent lines. The possibility of different disease reactions between breeding lines necessitated the development of a greenhouse testing procedure for screening seedlings for disease resistance. We undertook this study to determine the factors needed to create an artificial foliar blight epiphytotic in the greenhouse; to determine whether greenhouse damping-off trials could be used to evaluate breeding lines for resistance to foliar blight; and to compare greenhouse data with observations made in the field.

\section{MATERIALS AND GENERAL METHODS}

With one exception seedlings of $T$. vogelii for greenhouse studies were grown in sterilized soil in 4-inch pots for foliar-inoculation studies and in 20- x 12- x 4-inch metal pans and similar-sized wood flats for damping-off tests.

For inoculations in the greenhouse we used cultures of T. cucumeris and $M$. phaseoli derived from single foliar sclerotia taken from blighted plants growing at Lajas and Isabela, P.R., respectively. Inocula were prepared by comminuting mycelial mats of 1-week-old potato-dextrose broth cul-

${ }^{1}$ Plant Pathologist, (present address: P.O. Box 858, Mesa, Ariz.); Plant Geneticist, (present address: Plant Industry Station, Beltsville, Md.); Agronomist, and Biological Laboratory Technician, respectively, Crops Research Division, Agricultural Research Service; U.S. Department of Agriculture, Federal Experiment Station, Mayagüez, P.R.

${ }^{2}$ Italic numbers in parentheses refer to Literature Cited, p. 190. 
tures, grown in 125-ml. flasks, in sterile distilled water for 20 seconds in a blender. Foliar inoculations were performed by atomizing the inoculum on the foliage at 15 pounds per square inch. Soil inoculations for dampingoff trials in the greenhouse were conducted by in-furrow applications of inoculum at the rate of $10 \mathrm{ml}$. per 12 -inch row.

Disease reactions of lines of Tephrosia in damping-off trials in the greenhouse were based on percentage of control seedlings growing in sterile soil. Severity of foliar blight was classified by placing inoculated plants in one of the following disease classes: $0=$ no disease; $1=$ no defoliation, foliar lesions evident; $2=$ up to 25 -percent defoliation; $3=26$ to 50 -percent defoliation; $4=$ over 50 -percent defoliation; $5=$ plants dead. A disease index was calculated for each entry according to a formula devised by Sherwood and Hagedorn (5) as follows:

$$
\text { Disease index }=\frac{\begin{array}{c}
\text { sum } \\
\text { of }\left(\begin{array}{c}
\text { disease } \\
\text { class }
\end{array} \times \begin{array}{c}
\text { number of plants } \\
\text { in that class }
\end{array}\right) \times 100
\end{array}}{\begin{array}{c}
\text { total number } \\
\text { of plants }
\end{array} \times \begin{array}{c}
\text { number of } \\
\text { classes }
\end{array}}
$$

EXPERIMENTAL PROCEDURES AND RESULTS

\author{
GREENHOUSE EPIPHYTOTICS
}

\title{
Relative humidity
}

Most phytopathogenic fungi require a high relative humidity or free moisture to penetrate and infect a host plant. The effect of various postinoculation durations at 100-percent humidity was tested. Four-week-old test plants from P.I. 257533 were placed in a constant-mist chamber for 24 hours. The plants were removed from the chamber and atomized with a mycelial suspension, one mycelial mat per $100 \mathrm{ml}$. water, of T. cucumeris or $M$. phaseoli, and then returned to the chamber for $12,24,48$, or 72 hours of mist treatment. Additional plants were given a preinoculation mist treatment of 24 hours, inoculated, and then placed on the greenhouse bench. Another inoculated control group received no preinoculation or postinoculation mist treatment. All treatments were tested in six replications. The plants given postinoculation mist treatments were removed from the chamber after the specified durations and placed on the greenhouse bench. Disease readings were taken 14 days after inoculation.

Disease indices from this study are presented in table 1. An analysis of variance indicated that differences among treatments were significant. According to Duncan's Multiple Range Test (1), the disease severity of plants given a 24-hour preinoculation mist and either a 48-or 72-hour 
postinoculation mist treatment was significantly greater than for any other treatment regardless of pathogen.

Seedling age

Plants of T. vogelii grown in the field appeared to be more susceptible to foliar blight at a later stage of development. To determine the effect of seedling age on disease reaction in the greenhouse, 10 replications of 1-, 2-, 4-, and 8-week-old seedlings of P.I. 257533 were placed in a constantmist chamber for 24 hours, removed, and then inoculated with mycelial suspensions (1 mycelial mat per $100 \mathrm{ml}$. of water) of the test organisms. The plants were returned to the mist chamber for 48 hours, and then placed

TABLE 1.-Disease indices of Tephrosia vogelii seedlings subjected to various durations of 100-percent humidity before and after foliar inoculation with Thanatephorus cucumeris and Macrophomina phaseoli ${ }^{1}$

\begin{tabular}{|c|c|c|c|c|}
\hline \multicolumn{2}{|c|}{ Duration (hours) } & \multicolumn{3}{|c|}{ Disease indices ${ }^{2}$} \\
\hline Before & After & T. cucume & eris & M. phaseoli \\
\hline 0 & 0 & $0 \quad \mathrm{a}$ & & $4.2 \mathrm{a}$ \\
\hline 24 & 0 & $4.2 \mathrm{a}$ & & $12.5 \mathrm{a}$ \\
\hline 24 & 12 & 25.0 & b & 25.0 b \\
\hline 24 & 24 & 41.7 & $\mathrm{~b}$ & $45.8 \quad \mathrm{c}$ \\
\hline 24 & 48 & 70.8 & c & 100.0 \\
\hline 24 & 72 & 83.3 & c & 100.0 \\
\hline
\end{tabular}

\footnotetext{
${ }^{1}$ Disease readings recorded 14 days after inoculation; means of 6 replications.

${ }^{2}$ Based on 100 with $0=$ no disease, $100=$ plants dead; indices followed by the same letter are not significantly different at the 5-percent level (1).
}

on the greenhouse bench. Disease readings were made 7 days after inoculation, and disease indices were calculated.

Statistical analyses of the disease indices (table 2) indicated that disease severity was significantly greater in 2 -week-old seedlings inoculated with either pathogen, and in 8-week-old plants inoculated with $M$. phaseoli, than in all other age groups. Disease severity of 1-week-old seedlings was significantly lower than the severity of any other age group, whereas an intermediate disease reaction was obtained in 4 -week-old plants, regardless of pathogen.

\section{DAMPING-OFF STUDIES}

Selection of T. vogelii breeding lines for greenhouse studies was based on preliminary field observations. Lines were chosen that appeared to vary in disease reaction; no immune lines were observed. 
In the first of two damping-off studies we planted scarified seeds of five breeding lines: 642, 644, 647, 649, and 6410, and P.I. 257533 in metal pans in a completely randomized design. Each entry was represented 6 times, with a total of 90 seeds. Two concentrations of T. cucumeris and $M$. phaseoli were employed. The high concentration of mycelial suspension consisted of one mycelial mat per $100 \mathrm{ml}$. of sterile distilled water. The low concentration was prepared by diluting the high concentration 1:100 with sterile distilled water. Seedling survival was recorded 21 days after planting.

An analysis of variance of seedling germination in sterilized soil (control) indicated significant differences between entries due to variation in seed germination. Consequently, data on seedling survival were based on percentage of control survival.

TABLE 2.-Effect of age on foliar-blight severity of Tephrosia vogelii seedlings inoculated with Thanatephorus cucumeris and Macrophomina phaseoli ${ }^{1}$

\begin{tabular}{c|c|c}
\hline \multirow{2}{*}{$\begin{array}{c}\text { Seedling age } \\
\text { (weeks) }\end{array}$} & \multicolumn{2}{|c}{ Disease indices $^{2}$} \\
\cline { 2 - 3 } & T. cucumeris & M. phaseoli \\
\hline 1 & $34 \quad \mathrm{c}$ & $26 \mathrm{c}$ \\
2 & $98 \mathrm{a}$ & $92 \mathrm{a}$ \\
4 & $72 \mathrm{~b}$ & $68 \mathrm{~b}$ \\
$80 \mathrm{~b}$ & $78 \mathrm{a}$ \\
\hline
\end{tabular}

1 Means of 10 replications.

${ }^{2}$ Indices based on 100 with $0=$ no disease, 100 = plants dead; indices followed by the same letter are not significantly different at the 5-percent level (1).

An analysis of variance on the data (table 3 ) indicated that both pathogens incited significant damping-off. Differences in survival in soil inoculated with either the high or low concentration of $M$. phaseoli were not significant. However, the high concentration of T. cucumeris incited significantly more damping-off than the low concentration. There were no significant differences in disease reaction between the $T$. vogelii entries grown in soil inoculated with $M$. phaseoli, but survival of line 649 was significantly greater in soil inoculated with $T$. cucumeris than in the other entries.

A second trial was carried out using scarified seeds of four breeding lines: 642, 644, 647, and 649, and P.I. 257533. Each entry was planted in 12 replications, 10 seeds per replication. The inoculum suspension of each pathogen was prepared with three mycelial mats per 1,000 ml. of water; only one concentration was used. Seedling survival was recorded 21 days after planting.

Seedling survival in soil inoculated with $M$. phaseoli was not significantly 
different from survival of seedlings grown in sterile soil, but T. cucumeris incited significant damping-off. The differences in survival between breeding lines were not significant regardless of pathogen.

\section{Foliar inoculations}

Five breeding lines: 642, 644, 647, 649, 6410, and P.I. 257533, were tested in the greenhouse for their reaction to foliar inoculation with $T$. cucumeris and $M$. phaseoli. Each entry was replicated six times in a completely randomized design with an average of approximately 10 plants per replication. Inoculum concentrations were the same as those used in the

TABLE 3.-Survival of Tephrosia vogelii seedlings 21 days after planting in soil inoculated with Thanatephorus cucumeris and Macrophomina phaseoli at 2 levels of inoculum concentration (trial 1) ${ }^{3}$

\begin{tabular}{|c|c|c|c|c|}
\hline \multirow{2}{*}{ Line } & \multicolumn{2}{|c|}{ T. cucumeris } & \multicolumn{2}{|c|}{ M. phaseoli } \\
\hline & High $^{2}$ & Low ${ }^{2}$ & High & Low \\
\hline & Percent & Percent & Percent & Percent \\
\hline 642 & $38.5 \mathrm{~b}$ & $72.5 \mathrm{a}$ & $53.2 \mathrm{a}$ & $44.6 \mathrm{a}$ \\
\hline 644 & $30.3 \mathrm{~b}$ & $58.5 \mathrm{a}$ & $42.4 \mathrm{a}$ & $46.5 \mathrm{a}$ \\
\hline 647 & $34.1 \mathrm{~b}$ & $62.4 \mathrm{a}$ & $45.0 \mathrm{a}$ & $39.2 \mathrm{a}$ \\
\hline 649 & $59.5 \mathrm{a}$ & $71.0 \mathrm{a}$ & $51.1 \mathrm{a}$ & $48.5 \mathrm{a}$ \\
\hline 6410 & $38.9 \mathrm{~b}$ & $72.4 \mathrm{a}$ & $55.7 \mathrm{a}$ & $48.5 \mathrm{a}$ \\
\hline P.I. 257533 & $39.1 \quad b$ & $68.6 \mathrm{a}$ & $59.0 \mathrm{a}$ & $63.9 \mathrm{a}$ \\
\hline Average & 41.5 & 85.4 & 61.6 & 57.1 \\
\hline
\end{tabular}

${ }^{1}$ Percentages based on percentage survival of control seedlings growing in sterilized soil; means of 6 replications; means followed by the same letter are not significantly different at the 5-percent level (1).

${ }^{2}$ Levels of inoculum concentration.

second of the damping-off tests (three mycelial mats per $1,000 \mathrm{ml}$. of water). Two-week-old seedlings were given a 24 -hour preinoculation treatment in a mist-chamber, removed, inoculated, and then returned to the mist-chamber for 48 hours. Disease readings were taken 14 days after inoculation, and disease indices were calculated for each entry.

An analysis of variance of the disease indices obtained in the first experiment indicated that the differences in disease reaction between entries were not significant regardless of pathogen. T. cucumeris incited significantly more foliar blight than did $M$. phaseoli.

Another test was conducted in which surviving 4-week-old plants from the first trial of damping-off studies were divided into two groups, according to the pathogen used for soil inoculation, and placed on an intermittent-mist propagation bench for 24 hours. Each group was then atomized 
with a mycelial suspension, three mycelial mats per $1,000 \mathrm{ml}$. of water, of the same pathogen that previously had been incorporated into the soil in the damping-off experiment. The plants were returned to the propagation bench where they received a fine mist spray every 20 minutes. The foliage remained continually moist in this environment. Foliar blight recordings were made 3 weeks after inoculation, and disease indices were calculated.

An analysis of the data indicated that there were no significant differences in foliar blight severity between entries inoculated with T. cucumeris. But lines 647 and 649 exhibited significantly less foliar blight when inoculated with $M$. phaseoli than did the other entries. The difference in foliar blight between pathogens was highly significant, with $T$. cucumeris inciting the most severe reaction.

\section{FIELD EPIPHYTOTIC}

The 1963 and 1964 field nurseries of T. vogelii at Mayagüez were established at a location which had been in continuous Tephrosia plantings for approximately 5 years, and was known to have a high yearly incidence of damping-off and foliar blight. Both T. cucumeris and $M$. phaseoli have been isolated from diseased plants grown at Mayagüez.

The 1964 planting consisted of 12 breeding lines: 641, 642, 643, 644, 645, $646,647,648,649,6410,6411,6412$, and P.I. 257533, replicated 8 times in a randomized complete block design with 70 seeds per entry per replication. The plants were harvested approximately 7 months after planting. Final leaf:stem ratios (fresh weight) and yields of green leaves were adjusted on the basis of total stand and used as indications of the disease reaction of the lines to foliar blight.

The data, adjusted on the basis of stand obtained from the 1964 field planting at Mayagüez, are presented in table 4. None of the 12 breeding lines or P.I. 257533 exhibited a high degree of resistance to foliar blight as measured by leaf yield. Some lines, notably 644, 648, 6410, and 6411, showed an apparent tolerance to the disease, as evidenced by increased leaf:stem ratios. Although these lines were infected, they retained a greater percentage of their leaves than did lines that showed a tendency toward greater susceptibility. Leaf yield and leaf:stem ratio of P.I. 257533 tended to be lower than for other entries.

\section{DISCUSSION}

The necessity of high humidity for severe foliar blight in the greenhouse corresponded to what we have observed in the field. In the field the disease spread most rapidly in the early morning when the plants were wet with dew. Dry conditions retarded the growth of the pathogens over the surface of the plant, especially over young leaves that had not yet been invaded.

In the field at Mayagüez, P.R., T. vogelii plants seemed to become more 
susceptible to foliar blight with increasing age. However, this may be associated with increased inoculum density and the warm, humid environmental conditions present during the months of July, August, and September. Greenhouse studies indicated that, with only one exception, young plants were most susceptible-1-week-old seedlings with only their cotyledons expanded were resistant to attack, conceivably because the heavy cuticle of the cotyledons retarded fungus penetration.

Damping-off experiments did not detect measurable differences in resistance between the lines of $T$. vogelii inoculated with $M$. phaseoli. How-

TABLE 4.-Data from 12 breeding lines and 1 plant introduction of Tephrosia vogelii growing in a field at Mayagüez 6 months after planting ${ }^{1}$

\begin{tabular}{|c|c|c|c|c|}
\hline Line & Height & $\begin{array}{l}\text { Leaf weight per } \\
\text { plant }^{2}\end{array}$ & $\begin{array}{l}\text { Stem weight per } \\
\text { plant }^{2}\end{array}$ & Leaf:stem ratio \\
\hline & $\mathrm{Cm}$ & $\mathrm{Gm}$ & $\mathrm{Gm}$ & \\
\hline 641 & $136.8 \mathrm{a}$ & $139.39 \mathrm{ab}$ & $310.86 \mathrm{ab}$ & 0.438 bcde \\
\hline 642 & $133.4 \mathrm{a}$ & $111.53 \mathrm{ab}$ & $240.21 \mathrm{ab}$ & 0.427 abcde \\
\hline 643 & $125.3 \mathrm{a}$ & $86.48 \mathrm{ab}$ & $193.22 \mathrm{a}$ & .463 cde \\
\hline 644 & $139.2 \mathrm{a}$ & $127.94 \mathrm{ab}$ & $287.18 \mathrm{ab}$ & .497 de \\
\hline 645 & $129.1 \mathrm{a}$ & $97.71 \mathrm{ab}$ & $203.79 \mathrm{a}$ & 0.441 bede \\
\hline 646 & $143.1 \mathrm{a}$ & $118.95 \mathrm{ab}$ & $352.42 \mathrm{~b}$ & $0.350 \mathrm{abed}$ \\
\hline 647 & $125.0 \mathrm{a}$ & $66.62 \mathrm{a}$ & $238.32 \mathrm{ab}$ & $0.274 \mathrm{ab}$ \\
\hline 648 & $130.2 \mathrm{a}$ & $155.35 \mathrm{~b}$ & $314.94 \mathrm{ab}$ & .512 de \\
\hline 649 & $139.8 \mathrm{a}$ & $93.65 \mathrm{ab}$ & $304.96 \mathrm{ab}$ & $0.292 \mathrm{abc}$ \\
\hline 6410 & $129.1 \mathrm{a}$ & $121.41 \mathrm{ab}$ & $232.66 \mathrm{ab}$ & 0.477 de \\
\hline 6411 & $122.6 \mathrm{a}$ & $114.14 \mathrm{ab}$ & $212.63 \mathrm{ab}$ & $0.547 \quad \mathrm{e}$ \\
\hline 6412 & $124.0 \mathrm{a}$ & $127.22 \mathrm{ab}$ & $280.84 \mathrm{ab}$ & 0.411 abcde \\
\hline P.I. 257533 & $128.7 \mathrm{a}$ & $57.82 \mathrm{a}$ & $190.56 \mathrm{a}$ & $0.264 \mathrm{a}$ \\
\hline
\end{tabular}

${ }^{1}$ Average of 8 replications adjusted on the basis of stand; means followed by the same letter are not significantly different at the 5-percent level (1).

${ }^{2}$ Fresh weight.

${ }^{3}$ Based on fresh weight of leaves and stems.

ever, in one trial there was significantly less damping-off of seedlings of line 649 inoculated with T. cucumeris than occurred in any of the other entries. This apparent resistance of line 649 was not observed in the second damping-off trial.

Our earlier study (4) failed to demonstrate that $M$. phaseoli could incite damping-off of $T$. vogelii seedlings. However, in one trial of the present study, this organism induced significant damping-off. Although $M$. phaseoli appears to be a weak incitant only of damping-off in this crop, under certain conditions it may cause considerable reductions in stand.

Neither the greenhouse damping-off trials nor the foliar inoculation experiments demonstrated consistent differences in resistance of the six 
entries of $T$. vogelii to the two pathogens. The failure to detect significant differences may in part be ascribed to the severity of greenhouse epiphytotics, and also to a lack of extreme differences in resistance among entries. Even though entries appeared to be equally susceptible in greenhouse tests, differences in leaf yield and leaf:stem ratios among lines were observed in the field. Some of the differences were undoubtedly associated with inherent agronomic differences between lines, but a large portion was apparently due to differences in disease resistance.

All 12 of the breeding lines used in these studies were derived from crosses involving P.I. 257533 with several other plant introductions. The lines have undergone approximately 3 generations of selection under conditions of high disease infestations. We feel that most of the differences noted between P.I. 257533 and the various breeding lines resulted from recurrent selection pressure. Thus it appears probable that higher levels of resistance to foliar and damping-off pathogens can be isolated within the species. Therefore, the procedures described in this paper for greenhouse and field testing should be further refined and included as a routine part of the breeding program.

\section{SUMMARY}

The severity of foliar blight in T. vogelii incited by T. cucumeris and $M$. phaseoli was significantly greater for 48- and 72-hour periods of postinoculation humidity of 100 percent than for periods of 0,12 , and 24 hours.

Inoculations of 1-, 2-, 4-, and 8-week-old seedlings demonstrated that disease severity was significantly greater in the 2-week-old seedlings inoculated with either pathogen and in the 8-week-old seedlings inoculated with $M$. phaseoli, than in other age groups.

No consistent differences in resistance to the pathogens were detected among six entries of $T$. vogelii in damping-off trials and foliar inoculation tests in the greenhouse. However, differences were observed for leaf yield and leaf:stem ratios among 13 lines of $T$. vogelii which were tested in the field under a severe epiphytotic of foliar disease. Some of these differences were associated with disease resistance and the remainder with the inherent agronomic differences between lines.

\section{RESIMEN}

La severidad del tizón foliar causado por Thanatephorus cucumeris y Macrophomina phaseoli en Tephrosia vogelii fue significativamente mayor bajo condiciones de un 100 por ciento de humedad, en períodos de 48 y 72 horas que en períodos de 0,12 y 24 horas.

$\mathrm{Al}$ inocularse plantitas de 1, 2, 4 y 8 semanas con ambos patógenos, se encontró que la enfermedad fue significativamente más severa en las planti- 
tas que tenían 2 semanas de edad, en comparación con las de otras edades. Lo mismo sucedió con las plantitas de 8 semanas cuando se inocularon únicamente con $M$. phaseoli.

No se observaron diferencias consistentes en la resistencia de seis líneas de $T$. vogelii al sancocho y a inoculaciones foliares, en pruebas que se llevaron a cabo en el invernadero. En cambio se observaron diferencias en el número de las hojas producidas y en la proporción de las hojas a los tallos, en 13 líneas de $T$. vogelii que se sembraron en un campo severamente infestado con la enfermedad foliar. Algunas de estas diferencias se atribuyeron a la resistencia inherente a la enfermedad en las líneas bajo estudio y las demás a características agronómicas diferentes.

\section{LITERATURE CITED}

1. Duncan, D. B., Multiple range and multiple $F$ tests, Biometrics 11: 1-42, 1955.

2. Irvine, J. E., and Freyre, R. H., Occurrence of rotenoids in some species of the genus Tephrosia, Agr. Food Chem. 7: 106-7, 1959.

3. Ruppel, E. G., Barnes, D. K., Freyre, R. H., and Santiago, Alma, Effect of seed protectant and planting depth on Pythium and Rhizoctonia damping-off of Tephrosia vogelii in Puerto Rico, Plant Dis. Reptr. 48(9): 714-7, 1964.

4. Ruppel, E. G., Barnes, D. K., and Santiago, Alma, Potential of three Rhizoctonia species to incite foliar blight and damping-off on Tephrosia vogelii in Puerto Rico, Phytopathology 55(6): 612-4, 1965.

5. Sherwood, R. T., and Hagedorn, D. J., Determining the Common Root Rot Potential of Pea Fields, Univ. Wis. Agr. Exp. Sta. Bull. 531, 12 pp., 1958.

6. Theis, T., Freyre, R. H., and Kennard, W. C., Pellicularia filamentosa on Tephrosia vogelii and Cajanus indicus in Puerto Rico, F AO Plant Protection Bull. 5: 159-160, 1957. 